\title{
The Contribution of Intercessory Prayer in the Growth of the Early Church According to the Book of Acts
}

\author{
Bolean Silalahi \\ Universitas Kristen Indonesia \\ Email: boleansilalahi@yahoo.com
}

\begin{abstract}
The Contribution of Intercessory Prayer in the Growth of the Early Church according to the Book of the Acts provide a great role and influence for the growth and development of the Church. The Church as a Spiritual Organization craves healthy growth and development, both in quality and quantity. One of the most effective and efficient ways is to intercede, in addition to other methods of course. Nowadays, Intercessory prayer is receiving less serious attention in some churches. The growth and development of the Gospels according to what is written in the Book of Acts shows an event that resulted in major and prominent changes to be examined. There is a significant growth in the preaching of the Gospel both in terms of quality and quantity, many prayers delivered to God are fulfilled and accomplished. In the development of Mission and Gospel in this world it cannot be denied that there are certain individuals, even certain groups do not agree that the creation of a Church growth and development is caused by one of the supporting factors, namely Intercessory Prayer. Luke the writer of the Book of Acts reveals the extraordinary events experienced by Jesus's disciples. The outpouring of the Holy Spirit became the basis of everything that happened and the disciples obeyed the commandments. Behind these events there is a very important thing to remember, that they gather and pray, and even intercede for the fulfillment of God's promises for them and the world. Disciples are baptized, equipped, and even empowered by the Holy Spirit to carry out the Great Commission of Jesus Christ. There is no denying that this miraculous event in the Book of Acts has had a great impact until now. Because through this event many people became believers in Jesus Christ and accepted the Gospel in their lives. So that the Church is growing rapidly and extraordinary. Everything that happened during the Early Church was the key to the growth and development of the Church today. May Churches today increasingly realize that behind the Intercessory Prayer there is a real power that will be fulfilled by God for His people. Especially at this time of the Pandemic Covid-19, Intercessory Prayer is very urgent and important because the Churches needed the power of the Holy Spirit poured out for the Churches in this world.
\end{abstract}

Keywords: Intercessory, Prayer, Growth, Develop, Church.

\section{A. INTRODUCTION}

The Church as a Spiritual Organization longs for a healthy growth and development. Efforts to build a church that lives, grows and develops in a healthy manner, the Church must pray. In carrying out these activities the Church strives for various ways and one of them is through Intercessory Prayer. Based on the experiences written in the Bible in the Book of Acts 1:14, a Revival always begins with the gathering of several believers to intercede.

The level of success in evangelizing, pioneering and pastoring the Churches always has the role of Intercessory Prayer. Every church must perform intercessory prayer in the process of growth both in quality and quantity. It can be said that 
Intercessory Prayer is one of the important factors in the process of Church growth and helps save the Church's future. The church must make improvements and serious attention to the intercessory service. Very strange if a Church is said to be a growing Church, while Intercessory Prayer activities are not heeded even serious attention to the intercessory service. It is very strange if a Church is said to be a growing Church, while Intercessory Prayer activities are not heeded or not even carried out in Church service activities. In fact, as understood that the Church without Intercession cannot be categorized as a healthy Church. This means that intercessory prayer is a means of effective and efficient service for world outreach. Of course, by not ignoring other means. In this writing, the author wishes to discuss the importance of the Contribution of Intercessory Prayer in the Growth of the Early Church according to the Book of the Acts. The Book of Acts is one of the books that proves that Intercessory Prayer and the growth of the Church cannot be separated from each other. The author sees that Intercessory service is able to provide new breakthroughs in various spiritual services and produce life changes for believers, meaning that in the process of growth and development of service can be achieved through the role of Intercessory Prayer. To know the title of this paper and understand the flow of the discussion well, it is necessary to explain the understanding of the terms contained in the title of this paper: Contributions, this word refers to the meaning of: contributions (to associations), donations or an influence that has an impact. Intercessory Prayer, John Facius said: Intercessory Prayer is an attitude taken before God in a special situation and purpose to submit a request to God. He described as someone who went to become an intermediary between two groups in conflict and tried to avoid the form of problems.

J. D. Douglas defines Intercessory Prayer with a service that includes all the attitudes of the human spirit in his approach to God, in other words personal acknowledgment and understanding of the Divine will. In is a preposition to mark a place that contains content, or far down (from the surface), far into the middle, contains meaning (specific purpose), contains meaning (purpose), which is difficult to understand. Growth, the word growth implies development, progress. In the operational sense is a development in both quantity and quality. The church, in Greek, the curator of the Lord, the Christian congregation, the Church Building, the Christian denomination, or the body/organization of Christians who have the same faith. At first, it means first, at first, or the earliest origin. This means that the Church is the beginning or the beginning or the pioneering. According to this word, it means: according to or based on. In the operational sense it is based on the contents of the book discussed. Books, books that mainly deal with religion or science. In an operational sense it is the contents of reports of early church events. Story, is a story about an event (history) in someone's life. Acts, implies the person who received God's Revelation and to be delivered to humans, or the disciples of Jesus who first broadcasted about Christianity. So, the Book of Acts is one of the books in the New Testament that tells about the beginning of the Christian Church. So, this article discusses the extent of the contribution of intercessory prayer in the growth of the 
congregation and the Church towards a better direction and develops as the church's growth in the Early Church begins with the Book of Acts.

The purpose of this research is to explain the contribution of intercessory prayer in the process of the growth of the Early Church according to the Book of Acts both in quality and quantity. The importance of this research for Theological Education is that it can be used as a reference in the development of Theological Education specifically regarding Intercessory Prayer. For the universal Church to better understand and realize that Intercessory Prayer needs serious attention because it is very supportive in the process of Church growth. For the local Church to understand and understand the meaning of the power of Intercessory Prayer in the ministry of evangelism and pastoral care of the Church.

For the authors, the results of this study are to add insight into Intercessory Prayer because Intercessory Prayer is very important in the process of Church growth. If the congregation understands and understands the importance of Intercessory Prayer and conducts Intercessory Prayer as contained in the Book of Acts, then the Church will grow and develop. In limiting the scope of the discussion on the Contribution of Intercessory Prayer in the growth of the Early Church, the author specifically only bases this writing on the Book of Acts as the book that wrote the story of the Early Church. A rapid growth occurs in both quantity and quality. The author limits the writing to believers who gather and intercede to make breakthroughs in the fellowship and growth of the Early Church. So that leads them to a close relationship and a true knowledge of Jesus Christ the Son of God.

\section{B. METHOD}

This writing uses the method of library research. The author reads and studies the Bible, especially the Book of Acts as the main basis and is supported by references in Theology books, as well as Christian Religious Education literatures.

Systematics Writing is as follows:

Introduction. Consists of Background of Problem, Definition of Terms, Problem Formulation, Research Objectives, Research Importance, Hypothesis, Scope, Research Methodology, Explain the meaning of Intercessory Prayer, both in literature and theological, the biblical basis of Intercessory Prayer according to the Old and New Testaments, The Purpose of Intercessory Prayer. How to become an Intercessor, how to intercede, the Church and its understanding, the growth of the Church, and the biblical basis for the growth of the Church and people of God in the Old and New Testaments.

Describes the Bible's View of Intercessory Prayer, beginning with discussing the book itself, who was the author, the period of writing, the nature and purpose of the book, the motifs of the book related to history, Biography, Intercessory Prayer in the Church today, including in Church Services, prayer groups, prayer hills, full overnight prayers, and fasting and Intercessory Prayer.

Explanation of the Contribution of Intercessory Prayer in the growth of the Early Work according to the Book of Acts, Intercessory Prayer in the Book of Acts, 
starting from the Outpouring of the Holy Spirit, being baptized, equipped, empowered by the Holy Spirit and the Holy Spirit as intercessors. Types of Intercessory Prayers in the Book of Acts, Early Church Life, Church growth in quantity that includes, growing number of congregations, places won geographically, and quality growth which includes worship, fellowship, formation, ministry, testimonies, and Intercessory Prayer as a means in the growth of the Church. Comprehensive conclusion from the beginning to the end of the language of this writing, then concludes with Suggestions, both to the Church and to every believer, that the development and growth of the Church is greatly influenced by the Intercessory Prayer offered.

\section{RESULT AND DISCUSSION Description of Intercessory Prayer}

Niko Nyotohardjo in his book moving in Mission and Evangelism said: From year to year the message of God that is never forgotten is prayer. God will anoint intercessors more. Intercessors have a very big role ... especially in the harvest of souls ... It means that intercessory prayer is a very large task of the Church in the pace of service.

David Shibley also acknowledged this as noted in the Charismatic Renewal and Gospel Preaching of the World while saying: The greatest work placed in human hands is prayer and Intercessory Prayer. Prayer from God's side is communication between Himself and His allies. The Apostle Paul in his letter to Timothy also emphasized the same thing, which was to give instructions on how to maintain order in the local churches (1 Tim. 3: 14-15). Furthermore, in 1 Timothy 2: 1 , instructions for the ministry of prayer are mandated. "First of all, I advise you to raise the petition, the Intercessory Prayer and Thanksgiving." These three things can be firmly summarized in a word, which is to pray. To be able to understand well, first explained the understanding of the Intercessory Prayer.

Understanding Intercessory Prayer

Understanding the subject matter is the best first step in research. This is especially useful for avoiding misunderstandings and verbalism which can result in ambiguity in the meaning of a conversation. Then understanding Intercessory Prayer. Understanding the subject matter is the best first step in research. This is especially useful for avoiding misunderstandings and verbalism which can lead to ambiguity in the meaning of a conversation. Then this understanding is needed to clarify the next writing flow. Understanding Intercessory Prayer in this case will be seen from two sides of understanding. First, the literal understanding and second, theological understanding. Literally speaking of Intercessory Prayer, the first question that must be answered is what Intercessory Prayer means? Answering that question, the majority of people will likely answer that Intercessory Prayer is the same as prayer. If we re-understand God's Word, this answer would be strange because the word intercession is expressed separately from prayer (1 Timothy 2: 1). In the Big Indonesian Dictionary, the word prayer is defined as a request (hope, 
request, praise) to God. Douglas understands it as an all-encompassing service of the attitude of the human spirit in his approach to God ... to praise, acknowledge, and submit requests to Him. Dutch Sheet explains, intercessory prayer is a prayer of God, but intercession is something that people do in prayer.

Technically, intercession really isn't prayer. Thus, prayer and intercessory prayer clearly have different meanings. To understand the meaning that is true and proportional must conduct a research into the meaning of the intercessory prayer. In the Bible the word intercession can be found in 1 Timothy 2: 1: "First of all I advise: Raise requests, intercessions and thanksgiving for all people. In this verse there is no separation between the word prayer and intercession (the words prayer and intercession are not written). This is Paul's advice to the church he planted. In the King James Version of the Bible, intercession is translated as intercession. John M. Echols and Hassan Shadily translate the word by interference, intercession. According to Facius, the word describes a person present as an intermediary between two conflicting groups and tries to find a solution and prevent them from division. Going to pass between things, acting between two parties with the aim of reconciling those who differ or disagree, interfere, become intermediaries or intercede, intermediaries.

According to the same source, the word mediate is defined as being between two big differences, interfering with the two parties as equal friends for both, not impartial, holding negotiations between people with the aim of reconciling, mediating for peace, intercession. Noting the terms and definitions above are mostly the same as the words used to define the existing term, which is between interfering and reconciling. It should also be noted, one word is used to define another word. From this explanation, the concept of intercession can be summarized with the understanding: mediate, be in between, pleading for the interests of others, representing one party to another party.

Theologically, when a believer becomes an intercession in asking for God's mercy, that his gift be poured out for all those who are prayed for for salvation. The question that arises in logic is how God be willing to do the thing requested. While they (the prayers) never asked for it, they did not even want God to do this to them. But because Jesus Christ did it first, believers must emulate His example. He who has become Intercessor of humanity with God the Father through His requests and sacrifices. Henk Ten Napel defines intercession by means of. According to Sheets, every act mediated is Intercession. Kridalaksana defines Intercession as an intermediary in delivering requests to God. Napel went on to say that Intercessory is a prayer of intercession and intercessor is an intercessor. Sheets said: Christ, of course, is God's representative, mediator. He not only represents God among humans, but He also represents humans before God. This God - Man acts as a lawyer for both parties. He is the highest, the last and the only person who intercedes with us. He is the Apostle and High Priest whom we acknowledge, $\mathrm{He}$ is our intermediary. Jesus does not pray for us, but He intercedes for us so we can pray. This is the meaning of praying in His name. This means that believers' intercessory 
prayers are an extension of the intercession of Jesus Christ. God will not value other intermediaries besides Christ and only Him. Peter Wagner in his book Perisai Prayer explains: The word intercession comes from Latin which consists of two words, namely inter which means between and cedere, which is to go. Pointing to someone who is willing and willing to bridge, that is, a bridge for God and humans, or vice versa. This expression first refers to the Person of Christ as the Last Adam. This understanding is progressive and dynamic to be the incarnative model. This means that believers' intercessory prayers are an extension of the intercession of Jesus Christ. God will not value other intermediaries besides Christ and only Him. That definition is directed at the Church.

Theologically, the Church is a mediator or intercessor. Sheets completes this theological understanding in the expression that: Prayer of Intercession is the continuation of Jesus' ministry through His body, the Church in which we intercede between God and man with the purpose of reconciling the world Back to God, or severing the relationship between the devil and man with the aim of upholding victory in Calvary. To put it simply, it means standing in the middle of the divide to submit a petition before God. Prayers of the Supper of believers are an extension of the mediating work of Christ. God wants every Church to be a channel, intermediary, intermediate. God as the Winner wants His victory to be established through His Church. God as the Peace entrusted the ministry to believers as His work partner (cf. 2 Corinthians 5: 18-19). Believers represent Him in His ministry in the purpose of His redemption The Biblical Basis of Intercessory Prayer. The most clear words for the Intercessory Prayer is 1 Timothy 2: 1: "First, I advise you: Raise up the prayer, the intercession, and the thanksgiving for all." The Greek term used is enteuxeiz (enteuxeis: from the words en = en and teuxiz = teuxis).

Berry interprets it with intercessions. Barclay Newman translates the words enteuxeiz with prayer, pleading, pleading. A meeting with, meeting with, coming together, mediator, prayer, addressed to God for oneself or others (1 Timothy 2: 1; 4: 5, praying according to God's will). Intercessory Prayer can be defined as a prayer or prayer addressed to God both individually and collectively. Furthermore, Sheets says, Prayers of Prayer can also be interpreted as holy prayers, confidence, and diligence. Someone is asking God for one or more people who really need God's intervention. Only holy and pious people can pray for intercession. The Bible records the Prayer of Christ and the Holy Spirit and the Prayer of the righteous under the Old and New Testaments on.

\section{Old Testament}

The Old Testament as the Word of God is the basis for the implementation of the Intercessory Prayer. God has many great people who are faithful to God. They are used by God to reveal His prophecy, His will and purpose. In the Old Testament known leaders of the people of God, such as kings (cf. 1Chron. 21:17), prophets (cf. 1 Chron, 18: 41-45) and priests (Ezr, 9: 5-15) were in charge of the Prayer of Intercession for this nation. Examples of the great intercessory prayer of the Old 
Testament are the Abrahamic Intercession of Ishmael. In Genesis 17:18 it is said, And Abraham said unto God, Oh, that Ishmael might live before thee. Even when Abraham prayed for Sodom and Gomorrah even though the city was eventually destroyed by God (cf. Gen. 18: 23-32). Facius said: Let us see how Abraham began his defense and bargain before God and he kept pushing God by saying, "Lord if there are fifty righteous in this city, will you destroy the righteous along with the wicked?" and ... if fort ...The interesting part here is that God is moved to look for possible solutions. God took the initiative to call Abraham to intercede for Sodom and Gomorrah. Unfortunately, the conditions that God intended to save the city were not fulfilled. But one thing is certain, Abraham did pray. These efforts can be an example and basis of the Bible of Intercessory Prayer. In other cases, the Biblical basis of the Intercessory Prayer is David. When he prays for intercession for a child. In 2 Samuel 12:16 it is explained: Then David prayed to God for the child, and he fasted, and when he came in, he lodged there all night. And the elders of his house came and besought him that he would rise up from the floor; but he would not, neither did he eat bread with them (cf. Chronicles 29:19).

Intercessory prayers in the family can be seen in the life of Job and his children. In Job 1: 5, it is explained: "Whenever the days of the feast were past, Job called to them, and sanctified them. This is what Job always does." David and Job and other righteous men became mediators or human intercessors with God. They benefit from the existence of others and make it a struggle. Moses in the Old Testament is a prime example of the power of Intercessory Prayer. Many times, he prayed to God to change His will, even though God had already foretold what would happen. This event occurred when the Israelites rebelled against God on their way to the land of Canaan. God told Moses his servant that God would destroy them (Num, 14: 1-12). Moses brought all these questions to his intercessory prayer for their good (cf. Num. 14: 13-19). In the Bible's Modern Interpretation I explain: Moses immediately moved to intercede. None of the servants of God had ever been seated and failed to try the postponement or fail to persuade the people to destroy them, but Moses, his chosen one, did not intercede before him, to control his anger, until he don't destroy them. E.M. Bounds in his book Reach Prayer says: Moses' prayer was the only intermediate between God's wrath on the Israelites in line with His intention to destroy them.

The Hebrews were still alive but Sodom and Gomorrah could not be preserved. Others in the Old Testament who raised the Prayer of Supplication and Power, were Elijah (cf. 1 Chron. 18: 21-46), Daniel (cf. Daniel 9: 2-23), and Nehemiah (cf. Nehemiah 1: 3-11). They all act as mediators, petitioners to reconcile mankind's relationship with God and vice versa. They act as intercessors who share the pain and experience of people's lives, both as a nation, as families, and as leaders. Their Intercessory Prayer is able to change the way of life of a nation, both individually and as a group.

\section{New Testament}


In the New Testament, God works on the principle of community. According to David Pan Purnomo, fellowship comes from the word Koinonia (fellowship) which means sharing in brotherhood, faith, service and even property (Acts 2:44). Koinonia is achieved when everyone is willing to be governed and united by the Holy Spirit. The experience of Pentecost in the Bible becomes an important history of the birth of the Body of Christ. In their fellowship, God's people do Intercessory Prayer, and the answer depends on God's faith and will. John Bisagno agreed with this saying: The answered prayer requires two important factors. First, faith to believe. Second, God's willingness to bestow His blessings. At present, all of these brilliant principles are adopted as the biblical basis of Intercessory Prayer. If the Church believes that the God of Moses, Elijah, Paul is the same as God today, of course Intercessory Prayer is still relevant and its power still exists today. It must be believed that Intercessory Prayer is always emphasized and carried out in Church Growth both qualitatively and quantitatively.

New Testament Church

The New Testament churches often seek intercession for the needs of individuals. For example, the Church in Jerusalem gathered and authorized to pray for Peter's release from prison (compare Acts 12: 5, 12). Purnomo cited the opinion of D.L. Moody, saying: Diaconia is a Christian ministry. The Church is a mission, without a meaningless mission without the Church, the Associated Church is the Church that serves. God called and separated the Church from the world and then sent him back to the world on a mission. This way is an incarnative model of Jesus' ministry. The church in Antioch prayed for the success of Barnabas and Paul (compare Acts 13: 3). James specifically directed the elders of the Church to pray for the sick (compare James 5:14) and for all Christians to pray for the sick (compare James 5:16). The Apostle Paul went a step further and asked that the Prayers be interceded for everyone (compare 2 Timothy $1: 1-3$ ).

Paul as the leader shows that he is a prayer person, he deserves to be called a great intercessor. Paul does this with full awareness of its usefulness, especially as a church planter and leader. Octavianus said the absolute intercession for Christian leaders is to prioritize prayer. So that leadership does not become a barren, uninspired and authoritative leadership due to lack of prayer. In many of his letters Paul tells his own prayers for people and for the Church (compare Romans 1: 9-10). As also written in Ephesians 1: 15-19: Therefore, after I heard about your faith in the Lord Jesus and about your love for all the saints, I will not stop giving thanks because of you. And I always remember you in my prayers, and ask God our Lord Jesus Christ, that glorious Father, that he give you the Spirit of wisdom and revelation to know Him properly. And so that He makes the eyes of your heart bright, so that you understand what hope is contained in His calling, how rich the glory of His portion is for the saints, and how great is His power for those of us who believe, according to the power of those powers His.

Although Paul was an intercessor, he often asked the churches and congregations to pray for him. Paul was well aware that through prayer their 
ministry would be more successful. As written in Romans 15: 30-32: But for Christ's sake, our Lord, and for the love of the Spirit, I advise you, brothers and sisters, to struggle with me in prayer to God for me, so that I may be cared for from people who disobeyed in Judea, and that my service for Jerusalem was welcomed by the saints there, so that I who joyfully come to you by the will of God may be refreshed with you. The Apostle Paul in his ministry placed the Intercessory Prayer in the primary position. He counseled Timothy while writing 1 Timothy 2: 1. The Apostle Paul realized the importance of mediating people and connecting them to God. He really acts as an intercessor that connects sinners to the Creator so that the Holy Spirit works and convict sinners. In the mission of God's service, believers are used as mediators to bridge those who do not know the Lord Jesus Christ. An Intercessor must maintain the holiness of his life. Because Intercessory Prayer can only be done by the saints. People who are obedient and fear of God can offer Intercessory Prayer to God to divert and pour out His blessings.

During the Old Testament the life of God's people was always confronted with curses and blessings that led to destruction and salvation. This can be seen at the time of Abraham in Genesis 18: 23-33: Abraham came closer and said: Are you going to get rid of the righteous together with the wicked? What if there were 50 righteous people in that city? Will you destroy that place and will you not forgive it because of the fifty righteous people who are in it? Keep away from You to do this, to kill the righteous together with the wicked, so that the righteous are the same as the wicked! Keep this from you! Cook Judges all the earth does not punish justice! God says: ... (compare Numbers 14: 13-19; Joel 2:17) Abraham was the mediator in the efforts to restore His people, asking for help so that God undoed His intentions (compare Nehemiah 1, Daniel 9), so that God would release certain people from danger and blessed (Numbers 6: 24-26). Everything was done to get God's grace. The request was ultimately intended to honor and glory of God.

As said in Ephesians 1:12: that we who previously had put our hopes in Christ may be praises to His glory. Next in the Book of Acts 8: 15-17: when they arrived the two apostles prayed, so that the Samaritans would have the Holy Spirit. Because the Holy Spirit has not descended on any of them, because they were only baptized in the name of the Lord Jesus, then both of them laid their hands on them, then they received the Holy Spirit. Believers who are intercessors pray that the power of the Holy Spirit descends. Intercessor prayer is also a request through an intercessor, asking for one's healing. This is very clearly expressed in 1 Kings 17: 20-21: After that he called on the Lord, saying: O Lord, my God! Have you inflicted this misfortune on that widow, who accepted me as a passenger, by killing her child? Then he stretched his body over the child three times, and cried out to the LORD, saying: $\mathrm{O}$ Lord, my God! Put this child's life back into his body. Intercessory prayer is also intended for forgiveness of sins (compare Ezra 9: 5-15). Intercede so that the Holy Spirit gives power to those in authority and be given the ability to govern properly and correctly. Intercessory prayer for the growth of Christians in Christ as written in Philippians 1: 9-11, explained: And this is my prayer, may your love be more 
abundant in true knowledge and in all kinds of understandings, so that you can choose the good, so that you are holy and not flawed before Christ's day, full of the fruit of righteousness worked out by Jesus Christ to glorify and praise God. Request the leadership of the Holy Spirit to lead the Pastor to be an effective Shepherd (compare 2 Timothy 1: 3-7). For effective mission workers (compare Matthew 9:38), and the salvation of others (compare Romans 10:1) so that the person praises and glorifies God. All God's perfect will for His people revealed in the Bible can be the goal of Intercessory Prayer.

It is very appropriate if salvation and grace are used as the aim of Intercessory Prayer. Facius further said: one of the clearest goals of Intercessory Prayer we can find in God's Word is to awaken revival in the midst of the communities in which we live. The Bible explains that God still listens to the Intercession of His Church. This is true, because God never changes in His stand, but is always consistent with His promises. The intercessory prayers raised by His Church have a very strong role in the growth process of His Church, both qualitatively and quantitatively. William Barclay said: A praying church is a living and growing church. Next Tommy Tenney said, a Church without Intercessory Prayer is a dry house. It can be said that a church without intercessory prayer is a dead church and God does not want such a church. The purpose of Intercessory Prayer is simply to develop the Church of God, both spiritually and physically in terms of quality and quantity. This understanding should be maintained and believed by the Churches of God.

Intercession of the saints is a doctrine held by the Eastern Orthodox, Oriental Orthodox, and Roman Catholic Churches. The practice of praying through saints can be found in Christian writings from the 3rd century onward. The 4thcentury Apostles' Creed states belief in the communion of saints, which certain Christian churches interpret as supporting the intercession of saints. As in Christianity, this practice is controversial in Judaism and Islam.

\section{Intercession of the dead for the living}

On the basis of the intercession for believers by Christ, who is present at the right hand of God (Romans 8:34; Hebrews 7:25), it is argued by extension that other people who have died but are alive in Christ might be able to intercede on behalf of the petitioner (John 11:21-25; Romans 8:38-39). Aquinas quotes Revelation 8:4: "And the smoke of the incense of the prayers of the saints ascended up before God from the hand of the angel." Both those for and against the intercession of saints quote Job 5:1.

Jesus' parable of the rich man and Lazarus in Luke 16:19-31 indicates the ability of the dead to pray for the living. The intercession of the dead for the living is shown in 2 Maccabees 15:14-17; an intercession on behalf of Israel by the late high priest Onias III plus that of Jeremiah, the prophet who died almost 400 years earlier. "And Onias spoke, saying, 'This is a man who loves the brethren and prays much for the people and the holy city, Jeremiah, the prophet of God."' 


\section{Intercession of the living for the living}

According to the Epistle to the Romans, the living can intercede for the living: "Now I (Paul) beseech you, brethren, for the Lord Jesus Christ's sake, and for the love of the Spirit, that ye strive together with me in your prayers to God for me" (Romans 15:30). Mary intercedes at the wedding at Cana and occasions Jesus's first miracle. "On the third day a wedding took place at Cana in Galilee. Jesus' mother was there, and Jesus and his disciples had also been invited to the wedding. When the wine was gone, Jesus' mother said to him, 'They have no more wine.' 'Woman, why do you involve me?' Jesus replied. 'My hour has not yet come.' His mother said to the servants, 'Do whatever he tells you'”' (John 2:1-5).

When God was displeased by the four men who had attempted to give advice to the patriarch Job, he said to them, "My servant Job will pray for you, and I will accept his prayer and not deal with you according to your folly" (Job 42:8).

Moses says to God, "'Forgive the sin of these people, just as you have pardoned them from the time they left Egypt until now.' The Lord replied, 'I have forgiven them, as you asked"' (Numbers 14:19-20).

The elders of the church can intercede for the sick people. "Is anyone among you sick? Let them call the elders of the church to pray over them and anoint them with oil in the name of the Lord. And the prayer offered in faith will make the sick person well; the Lord will raise them up. If they have sinned, they will be forgiven" (James 5:14-15).

\section{Intercession of the living for the dead}

Intercession of the living for the dead is allegedly seen in 2 Timothy 1:16-18. "The Lord give mercy unto the house of Onesiphorus; for he oft refreshed me, and was not ashamed of my chain: But, when he was in Rome, he sought me out very diligently, and found me. The Lord grant unto him that he may find mercy of the Lord in that day: and in how many things he ministered unto me at Ephesus, thou knowest very well."

Roman Catholic Church doctrine supports intercessory prayer to saints. Intercessory prayer to saints also plays an important role in the Eastern Orthodox and Oriental Orthodox churches. In addition, some Anglo-Catholics believe in saintly intercession. This practice is an application of the Catholic doctrine of the Communion of Saints.

Some of the early basis for this was the belief that martyrs passed immediately into the presence of God and could obtain graces and blessings for others. A further reinforcement was derived from the cult of the angels which, while pre-Christian in its origin, was heartily embraced by the faithful of the sub-Apostolic age. According to St. Jerome, "If the Apostles and Martyrs, while still in the body, can pray for others, at a time when they must still be anxious for themselves, how much more after their crowns, victories, and triumphs are won!" The Catholic doctrine of intercession and invocation is set forth by the Council of Trent, which teaches that "...the saints who reign together with Christ offer up their own prayers 
to God for men. It is good and useful suppliantly to invoke them, and to have recourse to their prayers, aid, and help for obtaining benefits from God, through His Son Jesus Christ our Lord, Who alone is our Redeemer and Saviour." Intercessory prayer to saintly persons who have not yet been canonized is also practiced, and evidence of miracles produced as a result of such prayer is very commonly produced during the formal process of beatification and canonization. According to the Catechism of the Catholic Church: 956 The intercession of the saints. "Being more closely united to Christ, those who dwell in heaven fix the whole Church more firmly in holiness. .. . They do not cease to intercede with the Father for us, as they proffer the merits which they acquired on earth through the one mediator between God and men, Christ Jesus .... So by their fraternal concern is our weakness greatly helped."

Some Catholic scholars have reinterpreted invocation and intercession of the saints with a critical view toward the medieval tendencies of imagining the saints in heaven distributing favors to whom they will and instead seeing in proper devotion to the saints a means of response to God's activity in us through these creative models of Christ-likeness. With the exception of a few early Protestant churches, most modern Protestant churches strongly reject the intercession of the dead for the living, but they are in favor of the intercession of the living for the living according to Romans 15:30.

\section{Anglican views}

The first Anglican articles of faith, the Ten Articles (1536), defended the practice of praying to saints, while the King's Book, the official statement of religion produced in 1543, devotes an entire section to the importance of the Ave Maria ("Hail Mary") prayer. However, the Thirty-nine Articles (1563) condemn "invocation of saints" as "a fond thing, vainly invented, and grounded upon no warranty of Scripture, but rather repugnant to the Word of God" (Article XXII). Theologians within the Anglican Communion make a clear distinction between a "Romish" doctrine concerning the invocation of saints and what they view as the "Patristic" doctrine of intercession of the saints, permitting the latter, but forbidding the former. The bishop William Forbes termed the Anglican practice advocation of the saints, meaning "asking for the saints to pray with them and on their behalf, not praying to them". The Lutheran confessions approve honoring the saints by thanking God for examples of his mercy, by using the saints as examples for strengthening the believers' faith, and by imitating their faith and other virtues. However, the confessions strongly reject invoking the saints to ask for their help. The Augsburg Confession emphasizes that Christ is the only mediator between God and man, and that he is the one to whom Christians ought to pray.

\section{Reformed views}

Like Lutherans, strict Calvinists and other Reformed Christians understand the "communion of saints" mentioned in the Apostles' Creed to consist of all 
believers, including those who have died, but invocation of departed saints is regarded as a transgression of the First Commandment.

\section{Methodist views}

Article XIV of the Methodist Articles of Religion from 1784, echoing the Anglican Thirty-nine Articles, rejects invocation of saints by declaring the doctrine "a fond thing, vainly invented, and grounded upon no warrant of Scripture, but rather repugnant to the Word of God".

Judaism. There is some evidence of a Jewish belief in intercession, both in the form of the paternal blessings passed down from Abraham to his children, and 2 Maccabees, where Judas Maccabaeus sees the dead Onias and Jeremiah giving blessing to the Jewish army. In ancient Judaism, it was also popular to pray for intercession from Michael in spite of the rabbinical prohibition against appealing to angels as intermediaries between God and his people. There were two prayers written beseeching him as the prince of mercy to intercede in favor of Israel: one composed by Eliezer ha-Kalir, and the other by Judah ben Samuel he-Hasid. ${ }^{[26]}$ Those who oppose this practice feel that to God alone may prayers be offered. In modern times one of the greatest divisions in Jewish theology (hashkafa) is over the issue of whether one can beseech the help of a tzadik - an extremely righteous individual. The main conflict is over a practice of beseeching a tzadik who has already died to make intercession before the Almighty. This practice is common mainly among Chasidic Jews, but also found in varying degrees among other usually Chareidi communities. It strongest opposition is found largely among sectors of Modern Orthodox Judaism, Dor Daim and Talmide haRambam, and among aspects of the Litvish Chareidi community. Those who oppose this practice usually do so over the problem of idolatry, as Jewish Law strictly prohibits making use of a mediator (melitz) or agent (sarsur) between oneself and the Almighty. The perspectives of those Jewish groups opposed to the use of intercessors is usually softer in regard to beseeching the Almighty alone merely in the "merit" (tzechut) of a tzadik. Those Jews who support the use of intercessors claim that their beseeching of the tzadik is not prayer or worship. The conflict between the groups is essentially over what constitutes prayer, worship, a mediator (melitz), and an agent (sarsur).

The Intercession of the Spirit is the Christian belief that the Holy Spirit helps and guides believers who search for God in their hearts. In the Epistle to the Romans (8:26-27) Saint Paul states: In the same way, the Spirit helps us in our weakness. We do not know what we ought to pray for, but the Spirit himself intercedes for us through wordless groans. And he who searches our hearts knows the mind of the Spirit, because the Spirit intercedes for God's people in accordance with the will of God. There have been different theological interpretations of the intercession of the Spirit. John Calvin taught that it refers to the "teaching ministry of the Spirit" which instructs believers what to pray for and what to ask for in their prayers. On the other hand, Abraham Kuyper viewed the activity of the Spirit as separate and distinct from the efforts of the believers who pray. 
Intercession of Christ is the Christian belief in the continued intercession of Jesus and his advocacy on behalf of humanity, even after he left the earth. In Christian teachings, the intercession of Christ before God relates to Jesus' anamnesis before God during the Last Supper and the continuing memorial nature of the Eucharistic offering. From the Christological perspective, the intercession of Christ is distinguished from the Intercession of the Spirit. In the first case Christ takes petitions to the Father in Heaven, in the second case the Comforter (the Spirit) flows from Heaven toward the hearts of believers. The theological basis for the belief in the intercession of Christ is provided in the New Testament. In the Epistle to the Romans (8:34) Saint Paul states: It is Christ Jesus that died, yea rather, that was raised from the dead, who is at the right hand of God, who also maketh intercession for us. This intercession resonates with John 17:22 which refers to the "heavenly communion" between Christ and God the Father. ${ }^{[1]}$ The First Epistle of John (2:1-2) states: And if any man sin, we have an Advocate with the Father, Jesus Christ the righteous: and he is the propitiation for our sins; and not for ours only, but also for the whole world. In the Epistle to the Hebrews (7:25) Saint Paul wrote of the "salvation to the uttermost" through the continued intercession of Christ: Wherefore also he is able to save to the uttermost them that draw near unto God through him, seeing he ever liveth to make intercession for them. The intercession of Christ in Heaven is seen as a continuation of the prayers and petitions he performed for humanity while on earth, e.g. as in Luke 23:34: "Father, forgive them; for they know not what they do". In Pauline Christology the intercession of Christ has two components, both in the present and at the Last Judgement. This is expressed in Romans 8:33-34 in terms of "Who shall lay anything to the charge of God's elect?" and "Who is he that condemneth?", and then in Hebrews 7:25 in terms of the activities of Christ as the High Priest. In Christian teachings, the intercession of Christ before God relates to Jesus' anamnesis before God during the Last Supper and the continuing memorial nature of the Eucharistic offering. In the Christology of salvation, the one-time offering of Christ via his willing sacrifice at Calvary is distinguished from, but relates to his continued intercession from Heaven in his role as the High Priest, and his role at the Last Judgement. The notion of intercession by Christ as the Lamb of God relates to the imagery of the Lamb in Revelation 14:1:5 where those who are first saved "were purchased from among men" through the sacrifice of the lamb: These are they that follow the Lamb whithersoever he goeth. These were purchased from among men, [to be] the first fruits unto God and unto the Lamb. From the Christological perspective, the intercession of Christ is distinguished from the Intercession of the Spirit. While 1 John 2:1 states "We have an Advocate with the Father, Jesus Christ the righteous", John 14:16-17 includes the statement: And I will pray the Father, and he shall give you another Comforter, that he may be with you for ever, even the Spirit of truth: whom the world cannot receive; for it beholdeth him not, neither knoweth him: ye know him; for he abideth with you, and shall be in you. The distinction between the two forms of the advocacy can be interpreted in terms of the direction of the flow: in the first case Christ takes 
petitions to the Father in Heaven, in the second case the Comforter (the Spirit) flows from Heaven toward the hearts of believers.

The outpouring of the Holy Spirit can occur when interceding because the Pentecostal events in the Book of Acts begin with obedience and offer intercessory prayers. John Facius said: We cannot rule the Holy Spirit or make Him obey our commands, but on the contrary because the Holy Spirit is God Himself, we are the ones who should be obliged to obey His will and command.

No human can rule the Holy Spirit, not even the Bible records we are given the power to rule Him. The Holy Spirit is poured out on humans to fulfill the works written in the Bible. Sometimes there are times when we don't know what to pray for and how to pray well. The Holy Spirit helps us in our weaknesses because we do not know how to pray properly according to the will of the Father in Heaven. God the Father who searches the conscience knows the purpose of the spirit, namely that $\mathrm{He}$ is in accordance with God's will to pray for the saints (Romans 8: 26-27). In addition to the Holy Spirit empowering, baptizing, equipping, empowered by the Spirit. We must also know that Intercessory Prayer conta Paul as the leader shows that he is a prayer person, he deserves to be called a great intercessor. Paul does this with full awareness of its usefulness, especially as a church planter and leader. Octavianus said the absolute intercession for Christian leaders is to prioritize prayer. So that leadership does not become a barren, uninspired and authoritative leadership due to lack of prayer. In many of his letters Paul tells his own prayers for people and for the Church (compare Romans 1: 9-10). As also written in Ephesians 1: 15-19: Therefore, after I heard about your faith in the Lord Jesus and about your love for all the saints, I will not stop giving thanks because of you. And I always remember you in my prayers, and ask God our Lord Jesus Christ, that glorious Father, that he give you the Spirit of wisdom and revelation to know Him properly. And so that He makes the eyes of your heart bright, so that you understand what hope is contained in His calling, how rich the glory of His portion is for the saints, and how great is His power for those of us who believe, according to the power of those powers His important elements in human life because the Holy Spirit is the Intercessor for everyone who believes in God. The book of Acts is called the story of the Holy Spirit. This book is a book that records the growth process of the early church, which continues to grow and develop until now. Or also called the basis of Church growth. One of the characteristics of the early church was that they prayed together so that the impact was huge. Prayer plays an important role in fellowship. Early Prayer of Intercession (Acts 1: 13-14), this prayer meeting was the f irst prayer meeting held by the early church. Wesley said that the Church began with prayer and will continue to grow with the same power if we continue to pray like that. It means that with prayers like the early church did, we can do it too.

A congregation of 120 believers obediently awaits God's promise to be fulfilled to all of them. They gather and fellowship in prayer and even intercede for those who do not yet believe in Jesus, obedience leads them to God's holy promise. 
They even received extraordinary power from the Holy Spirit and miraculous signs and powers took place.

Peter's and John's Intercessions for the Samaritans (Acts 8: 14-17). The Samaritans are people who truly believe in Jesus Christ, they are baptized with water and in the name of Jesus, but have not been filled with the Holy Spirit as happened in Jerusalem when Jesus' disciples were praying. Peter and John went from Jerusalem to Samaria, laying their hands on the heads of new believers, praying for them, and they received the Holy Spirit. Wesley said: that they had the same power as those who had received the Holy Spirit in Jerusalem on Pentecost. The point is that the Holy Spirit and His power do not only belong to the Apostles but to all who believe because all of God's promises are not only for the disciples but for all believers and who walk in the leadership of the Holy Spirit to please God. The apostles only impart the power given by the Holy Spirit to them for believers. Cornelius Intercession (Acts 10: 2-6, 9, 31, 34).

Cornelius was not a Jew, but he prayed to God, because he was a prayer, so in answer to his prayers he was given a vision of angels who told him where he had to go so he could know God better. So that his prayer could be answered God gave a vision to Peter. While praying Peter was told to go to Cornelius' house and tell about Christ and His truth so that the whole house became Christians and was filled with the Holy Spirit. Wesley said that through the conversion of Cornelius and his household, the door to faith in the Gentiles was open. So it means that repentance does not only belong to the Jewish people but to all people, because before God we are all human beings His creation. This Cornelius story proves that God kept His promises. You will find Me, if you ask Me with all your heart (Jeremiah 29:13). NonJewish Christians are accepted at the level of Jews and do not need to be circumcised. This brings a new stage in the preaching of the gospel of Christ. Peter realized that the gospel was for all nations of the world. He realized that in the congregation there could not be rationalism in the New Testament prayer books, it was said that salvation was obtained by faith and not by carrying out religious regulations.

The point is that salvation cannot be regulated by humans or anything in this world. Because the right to salvation is a personal, private matter. Because only Jesus Christ the Savior of the world. Church Intercessory Prayer for Peter in prison (Acts 12: 5, 12-17). Peter came to Jerusalem to explain to the church about his actions at Cornelius' house. When Peter was there, Herod ordered to kill James, the leader of the Jerusalem Church, and planned the same thing with Peter after Easter, the congregation praying intercession day and night (Acts 12: 5). Stating that through prayers prayed God works extraordinary. The church became the mediator to free Peter from prison. Wesley said that Peter was chained, guarded by two soldiers and two bodyguard posts in front of the prison door. But an angel of God's messenger freed him, the chains broke, the prison door opened, the city gate opened by itself and the angel led Peter all the way in the city. It shows that the intercessory prayer offered is truly extraordinary. A person's life and death are not in the hands of 
humans, but in the hands of God, God's leadership and guidance are always present for believers. At that time the believers were not sure if the prayers that were raised would be answered extraordinary by the Lord. The Apostle Peter was free, the Jews were astonished and in the end the evil king was eaten by worms (Acts 12:23) and the Word of God resounded with great victory.

Dr. A. B. Simpson added that God does not want great people, but rather he wants people who dare to prove the greatness of their God. It means that God uses someone not because of his ability and intelligence, but God uses an ordinary person to be extraordinary because the Holy Spirit gives us the Spirit of courage.

Intercessory prayer is also one of the keys to the success of the growth and development of the Early Church. Early Church worship. In carrying out church services, do not worship in special places of worship like today. They do it in their respective homes. Kuhl added that in the first century believers allied and worshiped without using a neat system of worship. They pray together, worship, hear about Christian teaching and hold communion at every service and they are open to what the Holy Spirit says to them. In their worship system, the pattern seems to have strength and luck. Where worship is in a family atmosphere, know each other and have a real relationship in fellowship.

There are many opportunities for the congregation to know the gifts that are in themselves, so that they can function in the fellowships that are carried out and become active and responsible congregations. The outpouring of the Holy Spirit is an event that brings believers to live in the joy of God, communing together in the teaching of the apostles. The spread of the gospel only began after the great persecution in Jerusalem (Acts 8: 1-4). Obstacles and rejection of the name of Jesus for the first time, encouraging them to preach a greater and broader gospel, the Church becomes more open to all tribes and regions, there is no dividing wall between circumcised and uncircumcised. In this distribution it is not surprising that the church has spread to Judea, Galilee, Samaria, Italy and even to Spain. The preachers of the gospel preach it through trade channels that many communities gather, thus enabling them to listen to the preaching of the gospel by students who live in mingle with the surrounding community.

Karl Barth in his book Guanga says that worship of the church is Opus Dei, the Work of God, which is done for his own sake. True worship is a very high and noble activity carried out by a Christian to his God. Dyrness in his book entitled Themes in Old Testament Theology says that Worship is a response of believers' hearts to God. Trust the existence of God and respond to Him. God's main purpose in the context of penance is to bring His people back to God's Original Plan in the Creation, which is to live with Him.

\section{CONCLUSION}

The fulfillment of God's promise to His people on the Day of Pentecost made a history of great breakthroughs for the Church and mankind, which has had an 
impact to date. By obedience to the disciples' command of Jesus Christ before ascending to Heaven, they are baptized and equipped to be witnesses of the living Christ. They are changed to live and always intercede for mankind so that they become channels of the dynamic power of God. The occurrence of miraculous signs indicates that the gospel must be preached to the ends of the earth. The disciples progressed very rapidly in quantity, namely in the increase in the number of congregations and places that were won geographically from Jerusalem, Judea, Samaria and to the ends of the earth (Acts 1:8). Therefore, the victory achieved was not because of their strength but the influence of the Intercessory Prayer and the Power of the Holy Spirit that accompanied the apostles. The ministry of the apostles accompanied by miraculous signs made people come to Jesus and made them a militant and responsible congregation.

Live in worship, intercede, have close fellowship among the congregation, create social services, it is because they live in the teaching of the apostles of Jesus Christ so that their lives become independent and aware of the responsibilities of believers, namely to go out to preach the gospel for usurping souls for God. It cannot be denied that the success of the apostles in the ministry was due to their lives dependent on God, they were united and communed in sin so that the world would hear the gospel. That is why the beginning of the rapid growth of the Church because there is a big event happening in the Book of Acts that became the basis of the growth of the Church and this is God's goal for this world, which is to become one body with Christ. To re-create unity with God, the Churches of God must now unite and pray and leave all the attributes of the Church organization and return to teaching and service based on the Word of God. Intercessory prayer is made one of the factors that play an important role both in the organization of the Church or as the Body of Christ.

Because the existence of Intercessory Prayer in the Church will bring spiritual unity in the Church as the Body of Christ, one faith and one purpose. The apostles have set a good example for the world. For the Church and believers should always live in prayer because prayer is the breath of life of Christians. Without prayer, the life of believers will be easily fragile and faltering in the face of the various pressures of life in this world. When the Church and believers are united, the world will be won and the light of Christ will shine. Because the light is in every believer. The darkness of the world will be illuminated by the Glory of God. For the Pastors of the Assemblies and servants of God today, be intercessors for the world, and seize and win the world and those who do not yet believe in Christ. Because a great responsibility lies with all of them. Life that is always under the leadership of the Holy Spirit will make these miraculous signs happen again in the present time. Especially in dealing with the epidemic Covid-19 problem that is still rampant today. Deaths have fallen in various parts of the world, including Indonesia. The Pastors and Servants of the Lord have a great responsibility to God the Father. The hope of the Author through this article is that the Church and the Messenger of God go hand in hand according to God's will, through His Great Commission that brings 
souls (in quantity) and nurtures (in quality) those who have been won, so that they are born and grow A church that understands, understands, the duties and responsibilities that God has given us as His messengers, so that the miraculous signs that occurred in the days of Acts can occur again for the Unity of the Body of Christ on this earth.

\section{REFERENCES}

1. Bible New Translation. (1997) Jakarta: LAI

2. Indonesian-Greek Bible. (1997) Jakarta: LAI

3. Arikunto, S. (1985). Procedural and Strategic Education Research. Jakarta: Bina Aksara.

4. Barclay, W. (2000). Communicating the Gospel, Jakarta: BPK Gunung Mulia.

5. Barth, C. (1988). Old Testament Theology Series Volume 3. Jakarta: BPK Gunung Mulia.

6. $\quad$ Barnet, T. (1995). Miracles in your hands. Jakarta: YPI Immanuel.

7. Bisagno, J. (1995). The Power of Positive Prayer. Bandung: Kalam Hidup.

8. Bounds, E. M. (1994). Outreach Power of Prayer. Jakarta: YPI Immanuel.

9. Brougham, D. R. (2001) Planning a Mission through the Asian Churches. Malang: Gandum Mas.

10. Carson, D. A. (1997) New Testament Church and the Present. Malang: Gandum Mas.

11. Cho, P. Y. (1986). Key Prayer to Revival. Jakarta: YPI Immanuel.

12. Coleman, R. E. (1964). The Great Plan of the Agreement. Bandung: Kalam Hidup.

13. Douglas, J. D. (1995). Today's Bible Encyclopedia Volume 1. Jakarta: Yayasan Bina Kasih Komunikasi.

14. Indonesian National Encyclopedia, Volume 6. (1990). Jakarta: Literature Study.

15. Facius, J. (1994). Explanation of Intercessory Prayer. Jakarta: YPI Immanuel

16. Gerber, V. (1973) Church and Evangelism. Bandung: Kalam Hidup.

17. Gondowijoyo, J. H. (2002) Prayer School. Yogyakarta: Andi Offset.

18. Griffith, M. (2002). Church and Her Vocation Today. Jakarta: BPK Gunung Mulia.

19. Hagard, T. (2002). Church That Gives Life. Jakarta: Harvest Publication House.

20. Hagin, K. E. (1994). Christians as Bearers of Intercessory Prayer. Jakarta: YPI Immanuel

21. Halim, M. (2000) Church in the midst of World Change. Malang: Gandum Mas.

22. Hennichsen, W. A. (1974). How to Train Christ Students. Bandung: Kalam Hidup

23. Hinn, B. (1998). Biblical Road to Blessing. Jakarta: YPI Immanuel.

24. Horton, S. M. (1976). Person of the Holy Spirit, Malang: Gandum Mas.

25. https://en.wikipedia.org/wiki/Intercession_of_saints accessed on 04 July 2020

26. https://en.wikipedia.org/wiki/Intercession_of the Spirit accessed on 03 July 2020

27. https://en.wikipedia.org/wiki/Intercession_of Christ accessed on 01 July 2020

28. Jacobs, C. (1994). Occupying the Cities of God, Jakarta: Harvest Publication House

29. Jenson, R., \& Jim, S. (1996). Church Growth Dynamics. Stone: Lumen Christi. 
30. John, \& Sandforth, M. (1999). Inner Discharge and Healing. Jakarta: Nafiri Gabriel.

31. Kim, K. D. (2002). A Complete Desire of God's Will, Jakarta: Berea Indonesia.

32. Kridalaksana, H. (1993) Large Indonesian Dictionary. Jakarta: Balai Pustaka.

33. Marshal, C. (1986). The Holy Spirit of Our Help. Jakarta: BPK Gunung Mulia

34. Napel, H. T. (1996). Indonesian-English Theological Dictionary. Jakarta: BPK Gunung Mulia

35. Newman, B. M. (1994). Greek-Indonesian Dictionary. Jakarta: BPK Gunung Mulia.

36. Octavian, P. (1994). Management and Leadership according to God's Revelation. Malang: Gandum Mas.

37. Paimoen, E. (1999). Kingdom of God and Church. Bandung: Agiamedia.

38. Pardede, P. (1998). Church Growth. Yogyakarta: Andi Offset.

39. Pariadji, Y. (2003). Ministry, Power, Oil of Anointing-Baptism during Holy Communion. Jakarta: Betlehem

40. Poerwadarminta, W. J. S. (1980). Indonesian General Dictionary. Jakarta: Balai Pustaka

41. Purnomo, D. P. (1997). Answering Contemporary Questions. Malang: Time.

42. Riemer, G. T. T. (1999). Quality, Tomorrow's Christians are Determined by Current Communication. Jakarta: Yayasan Bina Kasih Komunikasi.

43. Senduk, H. L. (1985). Prayer Power. Jakarta: Bethel Foundation.

44. Sheets, D. (1999) Prayer of Intercession. Jakarta: YPI Immanuel.

45. Shibley, D. (1993). Charismatic Reform and World Gospel Message. Yogyakarta: Andi Offset.

46. Sijabat, S. B. (1994). Christian Education Strategies A Theological Review Philosophical. Yogyakarta: Andi Offset.

47. Stamps, D. C. (1996). The Guide to Abundant Life. Malang: Gandum Mas.

48. Stott, J. (1990) One People. Malang: Moment.

49. Tenney, T. (2000). God's Favorite House. Jakarta: YPI Immanuel.

50. Tong, S. (2001). The Holy Spirit, Prayer and Revival. Surabaya: Momentum.

51. Wagner, C. P. (1992). Perisai Prayer. Yogyakarta: Andi Foundation.

52. William, M. (1996). Prayers and Worship. Malang: Gandum Mas. 